\title{
Clinical Management and Outcome in Extreme Retroperitoneal Growing Teratoma Syndrome of Testicular Origin - Clinical Management and Effect of the Treatment
}

\author{
Extrémny prípad syndrómu rastúceho teratómu retroperitonea \\ testikulárneho pôvodu - klinický management a efekt liečby
}

\author{
Hulova S. ${ }^{1,2}$, Aziri R. ${ }^{3}$, Chovanec M. ${ }^{2}$, Mardiak J. ${ }^{2}$, Mego M. ${ }^{2}$, Pindak D. ${ }^{3}$ \\ 1 Department of Oncology, Central Military Hospital SNP Ruzomberok, Slovak Republic \\ 2 2nd Department of Oncology, Faculty of Medicine, Comenius University, National Cancer Institute, Bratislava, Slovak Republic \\ ${ }^{3}$ Department of Surgical Oncology, Slovak Medical University, National Cancer Institute, Bratislava, Slovak Republic
}

\begin{abstract}
Summary
Background: Growing teratoma syndrome (GTS) is an uncommon clinical finding in patients treated for testicular cancer. It is diagnosed during or after chemotherapy as an expanding tumour mass not responding to the treatment while the serum tumour markers are within the normal range. Pathological evaluation of resected tissue confirms the structures of benign mature teratoma. Case: Authors report a case of metastatic germ cell testicular cancer treated with 2 lines of chemotherapy and everolimus, that had finally been subjected for the resection of voluminous metastatic masses. We give a brief overview of current records concerning clinical management of GTS, and support the major role of surgical treatment in GTS. Results: Patient with metastatic mixed germ cell tumour of testis underwent a radical orchiectomy and completed the $1^{\text {st }}$ line treatment with BEP (bleomycin, etoposide, cisplatin) regimen. Radiographic restaging showed considerable disease progression to the retroperitoneum and supraclavicular lymph nodes. Second-line treatment with VIP (etoposide, ifosfamide, cisplatin) did not reverse the progression and the patient was consulted at our institute. Following the enrolment to the clinical study with everolimus, the patient exhibited continual metastatic growth in contrast to serum markers decrease. GTS was confirmed after resection of enormous retroperitoneal tumour mass, as well as from the specimen obtained from the subsequent supraclavicular and hepatal metastasectomy. The patient attained complete remission and has been closely observed over the last 31 months since the last surgery. Conclusion: GTS is resistant to chemotherapy and radiation and complete surgical resection results in excellent disease control. Clinicians should be aware of this infrequent presentation of testicular tumours, to ensure the timely diagnosis and the appropriate surgical removal without any delay. Despite the great extent and vital vasculature encasement, surgery may be feasible and successful, as we report in our case, consistently with the published data.
\end{abstract}

Key words

testicular neoplasms - teratoma - surgery - prognosis
The authors declare they have no potential conflicts of interest concerning drugs, products, or services used in the study.

Autoři deklaruji, že $v$ souvislosti $s$ predmětem studie nemaji žádné komerční zájmy.

The Editorial Board declares that the manuscript met the ICMJE recommendation for biomedical papers.

Redakční rada potvrzuje, že rukopis práce splnil ICMJE kritéria pro publikace zasílané do biomedicínských časopisů.

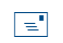

MUDr. Soňa Hulová

$2^{\text {nd }}$ Department of Oncology

Faculty of Medicine

Comenius University

National Cancer Institute

Klenova 1

83310 Bratislava

Slovak Republic

e-mail:misomego@gmail.com

Submitted/Obdržané: 25. 11. 2018

Accepted/Prijaté: 8. 1. 2019

doi: 10.14735/amko2019129 


\section{Súhrn}

Východiská: Syndróm rastúceho teratómu (growing teratoma syndrome - GTS) je zriedkavým klinickým nálezom u pacientov liečených pre nádory semenníkov. Zvyčajne sa diagnostikuje počas chemoterapie alebo po jejím absolvovaní ako expandujúca tumorózna masa neodpovedajúca na systémovú liečbu, zatial' čo onkomarkery v sére nestúpajú do patologických hodnôt. V prípade resekcie tumoróznej masy histologické vyšetrenie preukáže prítomnost' štruktúr benígneho zrelého teratómu. Prípad: Autori prezentujú prípad pacienta s metastatickým germinatívnym testikulárnym nádorom liečeného 2 líniami chemoterapie a everolimu predtým, než bol indikovaný na resekciu objemnej metastatickej masy v retroperitoneu. Článok obsahuje stručný prehlad súčasných poznatkov týkajúcich sa managementu GTS, ktorý podporuje hlavnú úlohu chirurgickej intervencie $\checkmark$ procese jeho liečby. Výsledky: Pacient $\mathrm{s}$ metastatickým zmiešaným germinatívnym testikulárnym nádorom podstúpil radikálnu orchiektómiu a 1. líniu systémovej liečby režimom BEP (bleomycin, etopozid, cisplatina). Radiologický restaging ukázal značnú progresiu ochorenia v oblasti retroperitonea a supraklavikulárnych lymfatických uzlín. Druhá línia chemoterapie VIP (etopozid, ifosfamid, cisplatina) nezvrátila priebeh choroby a pacient bol konzultovaný na našom pracovisku. Po splnení kritérií bol zaradený do klinickej štúdie s everolimom, počas ktorej však pokračoval metastatický rozsev, kým onkomarkery paradoxne klesali. Podozrenie na GTS bolo potvrdené histologicky z resekátu retroperitoneálnej tumoróznej masy, rovnako ako zo vzoriek získaných pri následnej supraklavikulárnej a hepatálnej metastazektómii. Pacient dosiahol úplnú remisiu ochorenia a ostáva v sledovaní aj 34 mesiacov od posledného zo série chirurgických výkonov. Záver: GTS neodpovedá na chemoterapiu ani radioterapiu a chirurgická liečba vedie k excelentnej kontrole ochorenia. Zvýšenie povedomia odborníkov o tejto nie častej prezentácii nádorov semenníkov môže zaručit včasnú diagnózu a adekvátnu chirurgickú intervenciu bez oneskorenia. Resekčný výkon je možný aj v prípade značne rozsiahleho nálezu a zavzatia vitálnej vaskulatúry a je výkonom kuratívnym, ako dokazuje náš prípad v súlade s už publikovanými údajmi.

\section{Klúčové slová}

nádory semenníkov - teratóm - chirurgická liečba - prognóza

\section{Introduction}

The growing teratoma syndrome (GTS) was first described in 1982 as a clinical finding among the patients with nonseminomatous germ cell tumour (GCT) treated with defined cytostatic therapy, who exhibited a massive metastatic growth in contrast to the decline of serum tumour markers [1]. GTS predominantly occurs in the retroperi-

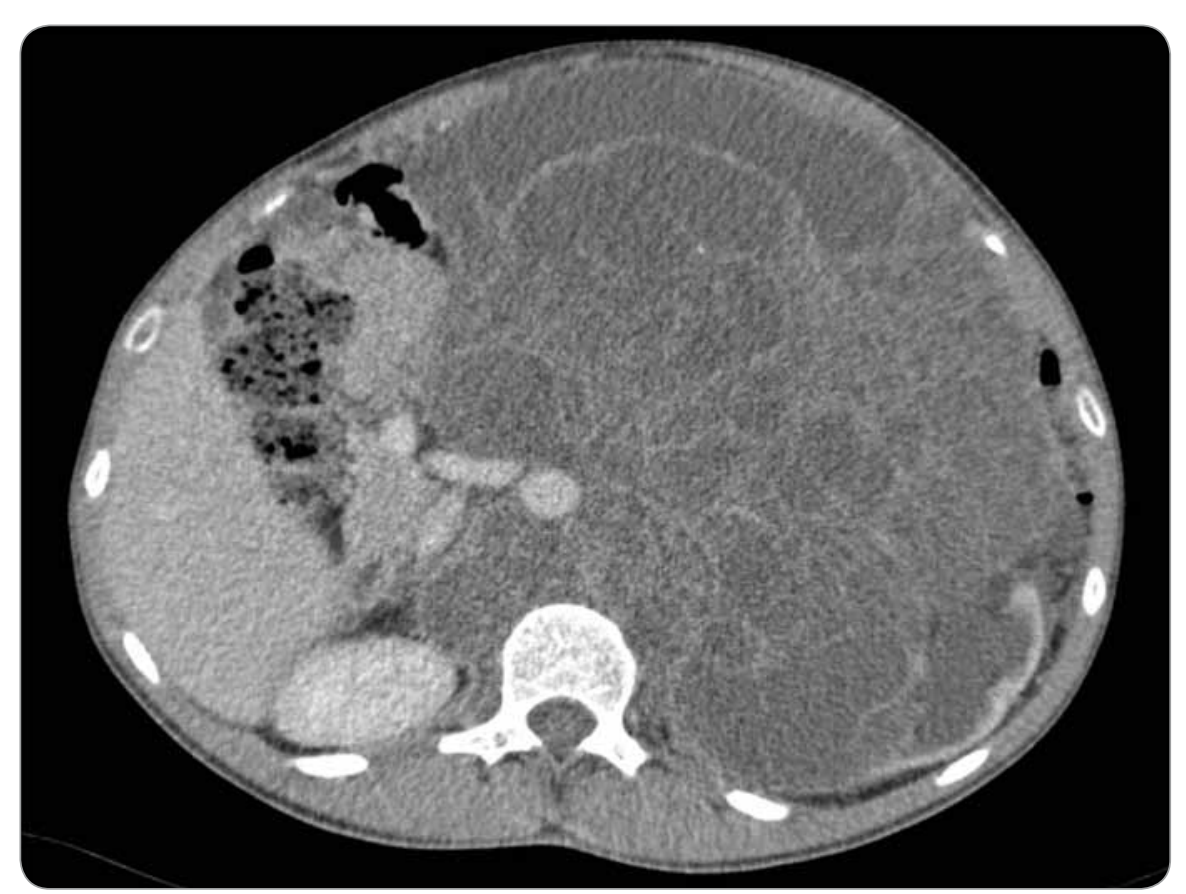

Fig. 1. Abdominal CT scan showing huge retroperitoneal mass encircling aorta and in-

ferior caval vein.

toneum and often encases the great vessels and adjacent organs [2]. Radiographic image includes solid and cystic components as well as necrotic areas [2]. Benign mature teratomas are resistant to chemotherapy and radiation, therefore only a complete surgical resection results in cure and is recognised as the treatment of choice based on published data [3-6].
We present a patient with advanced testicular GCT who had suffered from highvolume retroperitoneal disease and underwent a series of surgical interventions in order to remove several metastatic masses. $\mathrm{He}$ is still in complete remission 31 months after the last surgical procedure.

\section{Clinical case details}

We present the case of a 23-year-old patient with no relevant prior medical history, diagnosed with mixed GCT of testicular origin at the stage of metastatic disease (lungs, liver) who underwent a left-side orchiectomy. Histological examination described a tumour tissue specimen sized $15 \times 14 \times 9 \mathrm{~cm}$ with solid and cystic growth features, predominantly represented by teratoma cells (80\%), yolk sac tumour cells (10-15\%), including embryonal carcinoma cells $(<5 \%)$ and sporadic areas of choriocarcinoma. The disease was classified as pT2N3M1b, clinical stage IIIC, a poor-risk testicular cancer according to the International Germ Cell Consensus Classification criteria. Following the surgery, the patient was treated with four cycles of induction systemic therapy BEP (bleomycin, etoposide, cisplatin). Re-staging computed tomography (CT) scan revealed a massive disease progression in the retroperitoneum, volume expansion of the liver lesion and supraclavicular 
lymphadenopathy, pulmonary metastases remained unchanged. Subsequent $2^{\text {nd }}$ line treatment with three cycles of VIP (etoposide, ifosfamide, cisplatin) did not reverse the further progression, the retroperitoneal tumour mass expanded reaching $18 \mathrm{~cm}$ in diameter, and the hepatic lesion exhibited another enlargement. At this point, the patient was consulted at our institute and enrolled into the phase II clinical study for refractory GCT patients. He commenced the treatment with everolimus ( $10 \mathrm{mg} /$ day) 7 months after the orchiectomy. Initially elevated alpha-fetoprotein (AFP) $(11,47 \mathrm{U} / \mathrm{mL})$ dropped to the physiological value in 3 months, while beta-human chorionic gonadotropin ( $\beta-\mathrm{HCG}$ ) did not exhibit a pathological increase during the treatment course. Despite that, the retroperitoneal mass containing both solid and cystic components continually grew to $27 \times 18 \times 20 \mathrm{~cm}$ $(C C \times L L \times A P)$ (Fig. 1). Experimental therapy with everolimus had been administered for a 13-month period, when the patient was admitted to the surgical department for radical resection or at least, debulking procedure to relieve the intraabdominal hypertension syndrome.

During a 7.5-hour-operation procedure, the voluminous retroperitoneal tumour was resected en bloc, including the left hemicolectomy with terminal transversostomy and the left nephrectomy. Perioperatively, major blood loss caused by aortic wall infiltration required partial aortal resection and reconstruction with the Dacron patch use. Total blood loss assessment was $8,500 \mathrm{ml}$ and surgical complications included prolonged gastrointestinal paralysis, blood transfusions need and postoperative delirium (grade 2 according to Clavien-Dindo Classification). Left-sided supraclavicular metastatic mass of $8.4 \times 6 \times 5.4 \mathrm{~cm}(C C \times L L \times A P)$ (Fig. 2) extending to the mediastinum was completely resected 4 weeks later through collar approach and partial medial sternotomy. Finally, 3 months after retroperitoneal surgery, the metastasectomy of liver lesion in segment VII (Fig. 3) was performed along with the bowel stoma closure. All specimens obtained from the resections were histologically evaluated as the structures of mature teratoma.

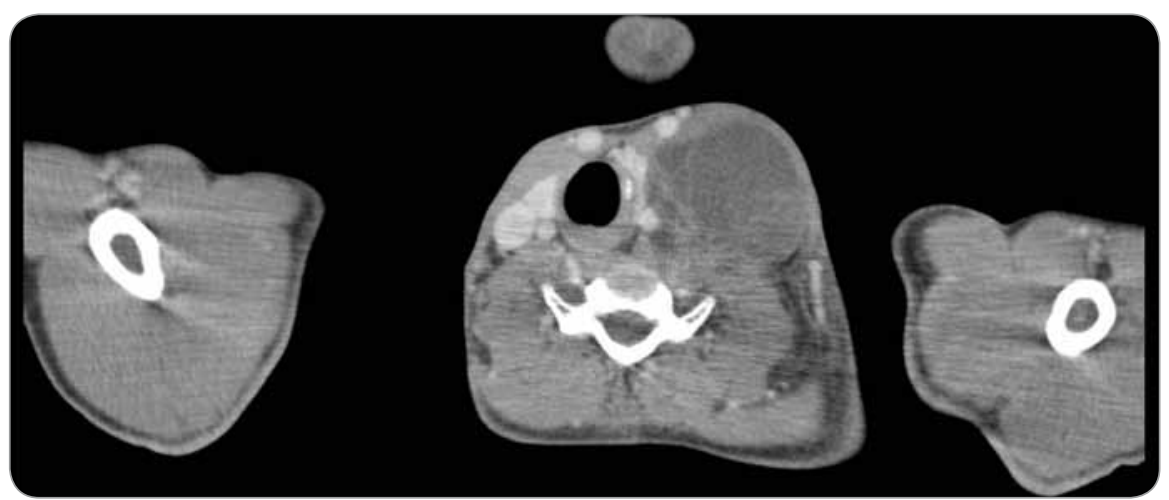

Fig. 2. Axial CT scan through left cervical tumor mass pressing thyroid gland and carotid and internal jugular vein.

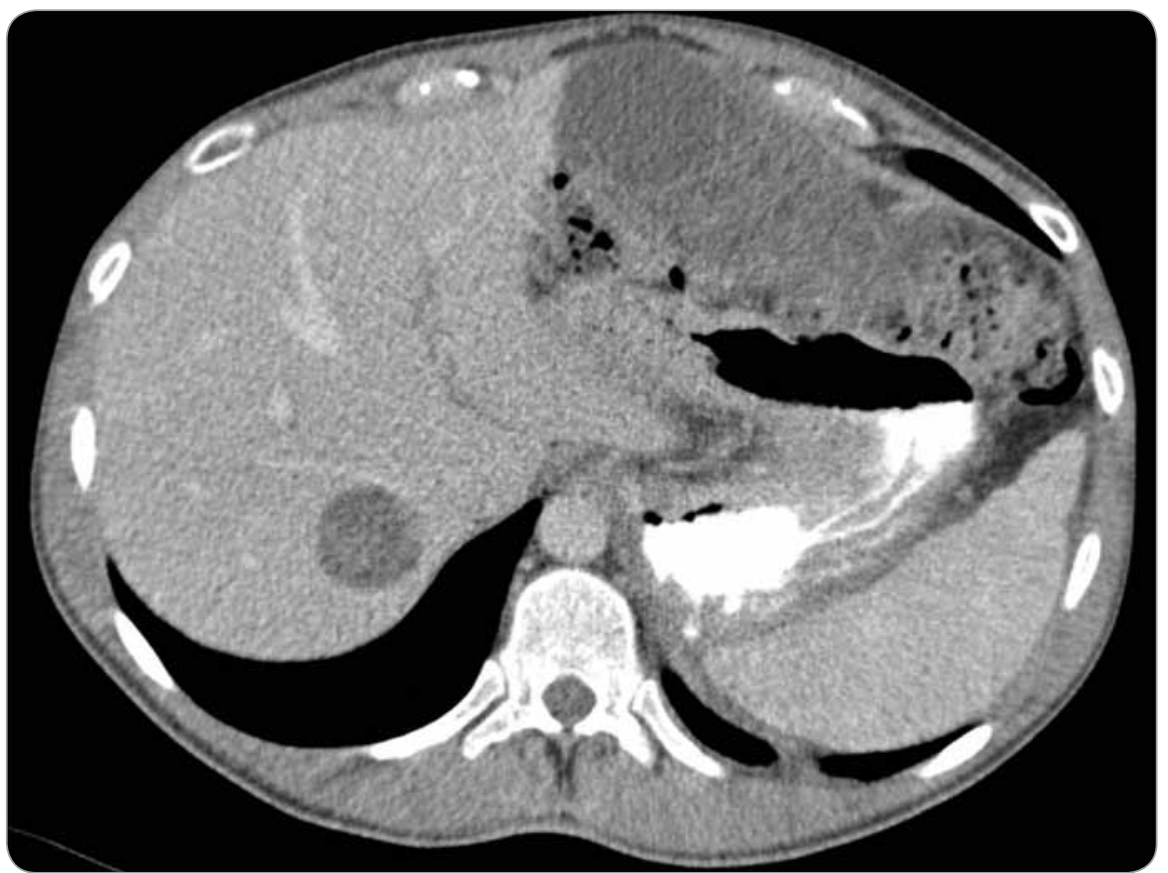

Fig. 3. CT scan of liver metastasis located in the segment VII.

Since then, the patient has been closely followed, without further systemic treatment. The serum markers are within the normal range and the CT scans repeatedly confirm the complete remission of the disease with mainly postoperative changes at sites of performed resections. The patient is 27 years old, able to work with good quality of life, asymptomatic, 31 months after the liver metastasectomy and 55 months from the primary diagnosis of metastatic mixed testicular GCT.

\section{Discussion}

GTS is a rare clinical finding among patients with testicular and ovarian GCT with the vast majority of cases described in men since testicular GCT is more prev- alent [7]. The prevalence of GTS in metastatic nonseminomatous GCT according to the published data is between $2-7.6 \%$ whereas occasionally, it may originate in pure seminoma [5]. Predominantly located in the retroperitoneal area, growing teratoma also occurs in the lungs, liver, mediastinum, forearm, supraclavicular and inguinal lymph nodes $[2,8]$. Three criteria have been established to define the diagnosis of GTS. Considering the fact that the overall survival rates in advanced testicular cancer reach $90 \%$ following the combination of cisplatin-based regimen and surgery, tumour growth during or after chemotherapy administration may be the first sign of growing teratoma development. Sec- 
ondly, normalisation of serum tumour markers associated with evident tumour enlargement is usually observed although minor elevations have been reported occasionally [9].

The histological presence of mature teratoma components at the time of the resection and no viable germ cells is the third condition to fulfil the GTS diagnosis [1]. The association between primary pathology and the likelihood of GTS has not yet been well recognised. The pathogenesis of GTS remains unclear and presumably includes the chemotherapy-induced transformation of totipotent malignant germ cell into a mature teratoma and selective destruction of immature malignant cells allowing for the growth of the benign mature teratoma. Moreover, the animal model proposes an inherent and spontaneous differentiation of malignant cells into benign tissues $[2,8,10,11]$.

GTS has a variable time-course presentation with early reports after two cycles of systemic therapy to more than 10 years after chemotherapy completion, mostly occurring within 24 months $[12,13]$. Growing teratoma typically presents with cystic components and necrotic areas on CT imaging and its margins are relatively well circumscribed [3]. The treatment with $18 \mathrm{~F}$-fluorodeoxyglucose positron emission tomography might be useful for the assessment of residual tumour viability, however, relatively low sensitivity and specificity as well as possible false positive findings caused by chemotherapy-induced recruitment of neutrophils, lymphocytes and macrophages, limit the routine utilisation of this method in patient monitoring [14].

To date, no specific growth size/rate has been correlated to GTS [13]. Normalisation of serum tumour markers (AFP, HCG, lactate dehydrogenase) concurrent with the tumour growth is a typical feature of GTS. In cases where the tumour markers decline but remain slightly over the normal range, active immature carcinomatous components may be present. However, it is necessary to exclude a non-malignant aetiology of the increase (liver dysfunction, luteinizing hormone cross reactivity in patients with hypogonadism, the use of marijuana, etc.) [15]. An atypical clinical finding in ovary-associated GTS was described as gliomatosis peritonei, a condition characterised by the presence of mature glial tissue in the peritoneum [7].

GTS is unresponsive to chemotherapy and radiation, and a timely radical surgical excision is considered a golden standard of treatment [3-6]. Massive retroperitoneal expansion, especially when encompassing the great vessels, may be deemed unresectable and the patient is thereby sentenced to palliative care. Current clinical experience consistently with our case proves that even the highvolume disease can be completely resected with an excellent prognosis [16]. A delay in surgery may result in unfavourable clinical scenarios, such as malignant somatic transformation (3-6\% of cases) or compression of adjacent structures. Such delay will ultimately worsen the outlook for the complete resection which guarantees a 10-year recurrence-free survival of approximately $80 \%[17,18]$. Unresectable disease has become a candidate for medical stabilisation. Promising reports of treatment response after bevacizumab, cyclin-dependent kinase inhibitors, and interferon have been published, thus encouraging further research $[19,20]$.

\section{Conclusion}

Uncommon clinical course of treated GCTs described as GTS may result in misdiagnosed disease progression and cause the oncological overtreatment in a number of patients. Considering the favourable prognosis of treated metastatic testicular tumours, extensive tumour growth associated with the normalisation of serum tumour markers should raise suspicion of mature teratoma formation. It often encases vital vasculature and adjacent structures and complete surgical resection as the golden standard of GTS treatment may not always be feasible. We highlight the favourable prognosis of patients with GTS after complete resection and encourage the specialists involved not to postpone the surgical procedure. Furthermore, we emphasise the role of active monitoring and coordinated surgical and oncological care in patients with advanced testicular cancer as these are crucial to optimise the outcome of GTS, especially in high-volume disease.

\section{References}

1. Logothesis CJ, Samuels ML, Trindade A et al. The growing teratoma syndrome. Cancer 1982; 50(8): 1629-1635. 2. Gorbatiy V, Spiess PE, Pisters LL. The growing teratoma syndrome: current review of the literature. Indian J Urol 2009; 25(2): 186-189. doi: 10.4103/0970-1591.52910.

3. Lee DJ, Djaladat $\mathrm{H}$, Tadros NN et al. Growing teratoma syndrome: clinical and radiographic characteristics. Int J Urol 2014; 21(9): 905-908. doi: 10.1111/iju.12466.

4. Daneshmand S, Albers P, Foss SS et al. Contemporary management of postchemotherapy testis cancer. Eur Urol 2012; 62(5): 867-876. doi: 10.1016/j.eururo.2012.08.014. 5. André F, Fizazi K, Culine $S$ et al. The growing teratoma syndrome: results of therapy and long-term follow-up of 33 patients. Eur J Cancer 2000; 36(11): 1389-1394.

6. Aide N, Comoz F, Sevin E. Enlarging residual mass after treatment of a nonseminomatous germ cell tumor: growing teratoma syndrome or cancer reccurence? J Clin Oncol 2007; 25(28): 4494-4496. doi: 10.1200/JCO.2007.12.7530. 7. Bentivegna E, Azais H, Uzan C et al. Surgical outcomes after debulking surgery for intraabdominal ovarian growing teratoma syndrome: analysis of 38 case. Ann Surg Oncol 2015; 22 (Suppl 3): 964-970. doi: 10.1245/s10434-015-4608-y.

8. Boukettaya W, Hochlaf M, Boudagga Z et al. Growing teratoma syndrome after treatment of a nonseminomatous germ cell tumor: a case report and a review of literature. Urol Case Rep 2014; 2(1): 1-3. doi: 10.1016/j. eucr.2013.11.007.

9. Jeffery GM, Theaker JM, Lee AH et al. The growing teratoma syndrome. Br J Urol 1991; 67(2): 195-202.

10. Nimkin K, Gupta P, McCauley R. The growing teratoma syndrome. Pediatr Radiol 2004; 34(3): 259-262. doi: 10.1007/s00247-003-1045-Z

11. Hong WK, Wittes RE, Hajdu ST. The evolution of mature teratoma from from malignant testicular tumors. Cancer 1977; 40(6): 2987-2992.

12. Djordjevic B, Euscher ED, Malpica A. Growing teratoma syndrome of the ovary: review of literature and first report of a carcinoid tumor arising in a growing teratoma of the ovary. Am J Surg Pathol 2007; 31(12): 1913-1918. doi: 10.1097/PAS.0b013e318073cf44.

13. Kataria SP, Varshney AN, Nagar M et al. Growing teratoma syndrome. Indian J Surg Oncol 2017; 8(1): 46-50. doi: 10.1007/s13193-016-0568-3.

14. Büchler T, Simonova K, Fencl P et al. Pozitronová emisní tomografie $v$ diagnostice a sledování pacientu s neseminomovými germinálními nádory. Klin Onkol 2011; 24(6): 413-417. doi: 10.14735/amko2011413.

15. Spiess PE, Tannir NM, Tu SM et al. Viable germ cell tumor at postchemotherapy retroperitoneal lymph node dissection: can we predict patients at risk of disease progression? Cancer 2007; 110(12): 2700-2708. doi: 10.1002/cncr.23104

16. Beck SD, Fister RS, Bihrle R et al. Long-term outcome for patients with high volume retroperitoneal teratomaundergoing post-chemotherapy surgery. J Urol 2009; 181(6): 2526-2532. doi: 10.1016/j.juro.2009.01.116. 17. Carver BS, Shayegan B, Serio A et al. Long-term clinical outcome after postchemotherapy retroperitoneal lymph node dissection in men with residual teratoma. J Clin Oncol 2007: 25(9): 1033-1037. doi: 10.1200/JCO.2005.05.4791. 18. Nassiri N, Shah A, Daneshmand S et al. Growing teratoma syndrome of testicular origin. Urology 2019; 123: 20-23. doi: 10.1016/j.urology.2018.05.015.

19. Mego M, Reckova M, Sycova-Mila Z et al. Bevacizumab in a growing teratoma syndrome. Case report. Ann Oncol 2007; 18(5): 962-963. doi: 10.1093/annonc/mdm125. 20. Vaughn DJ, Flaherty K, Lal P et al. Treatment of growing teratoma syndrome. N Engl J Med 2009; 360(4): 423-424. doi: 10.1056/NEJMc0808558. 